\title{
Spatial and Temporal Patterns of Aspergillus flavus Strain Composition and Propagule Density in Yuma County, Arizona, Soils
}

\author{
Thomas V. Orum, Donna M. Bigelow, and Merritt R. Nelson, Department of Plant Pathology, University of Ari- \\ zona, Tucson 85721; Donald R. Howell, Cooperative Extension Service, University of Arizona, Yuma 85364; and \\ Peter J. Cotty, Southern Regional Research Center, USDA, ARS, New Orleans, LA 70179
}

\begin{abstract}
Orum, T. V., Bigelow, D. M., Nelson, M. R., Howell, D. R., and Cotty, P. J. 1997. Spatial and temporal patterns of Aspergillus flavus strain composition and propagule density in Yuma County, Arizona, soils. Plant Dis. 81:911-916.

Aspergillus flavus isolates from Arizona can be divided into S and L strains on the basis of sclerotial morphology. These genetically distinct strains differ in aflatoxin production. To help understand factors influencing the aflatoxin producing potential of $A$. flavus communities, spatial and temporal patterns of strain incidence were compared with patterns of A. flavus propagule density in Yuma County soils. Strain S isolates were found in all sampled fields, but the percentage of strain $\mathrm{S}$ isolates ranged from 4 to $93 \%$. A nested analysis of variance was used to determine the spatial scale at which most variability in strain composition and propagule density occurred. For both variables, the largest component of variance occurred among fields within areas at a spatial scale of 1 to $5 \mathrm{~km}$. There was also spatial structure (12 to $21 \%$ of the variance) at the subregional level $(>20 \mathrm{~km})$ in strain composition, but not in propagule density. Temporal patterns for both variables were similar. The sampling periods with the highest incidence of strain S isolates, August 1994 (60\%) and July 1995 (62\%), occurred during cotton boll formation. The regional average for A. flavus propagule density was near 1000 propagules/g in the summer, but less than 100 propagules/g in the spring. The results suggest that insights into factors influencing the toxigenicity and propagule density of A. flavus communities might be achieved most readily by contrasting fields in close spatial proximity.
\end{abstract}

Additional keywords: geographic information systems, geostatistics, GIS

Aspergillus flavus Link:Fr. is a soilinhabiting fungus that saprophytically utilizes a wide range of organic substrates. From an agro-ecological perspective, it is an important degrader of crop debris contributing to nutrient recycling (11). A. flavus first attracted the attention of cotton researchers in the early 1950 s, when it was associated with a fluorescent fiber condition of raw cotton (14). About a decade later, cottonseed meal was implicated in a widespread epidemic of trout liver cancer (18). The cause was subsequently found to be aflatoxins produced by A. flavus (12). Cottonseed is a preferred feed for dairy cows and, with the demonstration that aflatoxins were passed from feed to milk, aflatoxin content of cottonseed became regulated closely. An aflatoxin content greater than $20 \mu \mathrm{g} / \mathrm{kg}$ prevents dairy use and associated premiums. Thus, the aflatoxin content greatly influences the market value of cottonseed.

Corresponding author: T. V. Orum

E-mail: torum@ag.arizona.edu

Accepted for publication 24 April 1997.

Publication no. D-1997-0610-01R

(C) 1997 The American Phytopathological Society
In Arizona, A. flavus isolates can be divided into two strains, $\mathrm{S}$ and $\mathrm{L}$, on the basis of sclerotial morphology ( $\mathrm{S}$ for small, L for large) (4). Each strain is composed of many vegetative compatibility groups (VCGs) (2). Gene flow is limited among VCGs and, as such, sites are occupied by communities of $A$. flavus VCGs rather than a single A. flavus population (2). Strain composition is determined by the percentage of isolates that are $\mathrm{S}$ strain or $\mathrm{L}$ strain. S strain isolates consistently (> 98\%) produce large amounts of aflatoxin in infected cotton bolls, whereas L strain isolates on average produce much less aflatoxin, with some producing no aflatoxin at all (4). The two strains can be differentiated on culture media, and strain incidence can provide a rapid estimate of the toxigenicity of an $A$. flavus community. The toxigenicity of the A. flavus community in a field may be an important determinant of the extent of aflatoxin production within crops. The average toxigenicity of $A$. flavus communities differs significantly across the southern United States, as well as within Arizona, and is significantly correlated with $S$ strain incidence (9).

Spatial and temporal analysis of plant pathogen communities may provide insights that are useful in plant disease management. Initial spatial analysis of a variable requires determination of the scale or range of distance over which most variability occurs. Subsequent research may then be directed at the scale of greatest variance and emphasize interpretation of spatial patterns at the appropriate scale. Factors varying at a scale similar to the pathogen may then be sought and the putative influence of these factors on the pathogen empirically evaluated. Patterns caused by landscape, crop sequence, climate, and tillage may each differ in scale, and the influence of each factor may cause variance at different scales in a pathogen population. Determination of spatial scale can be efficiently done using a nested analysis of variance $(15,17)$.

In the current study, our primary goal was to determine the spatial scales in which most variability occurs for both $A$. flavus strain composition and propagule density. In the process, we also assessed both the temporal stability of spatial scale and temporal variability in A. flavus propagule density and strain composition.

\section{MATERIALS AND METHODS}

Thirty commercial fields were selected from a cross-section of Yuma County cultivated land, ranging from Texas Hill on the east to San Luis in the southwestern corner of the county. Soil samples were collected according to a nested sampling design to assess A. flavus communities over several spatial scales which were named "subregions" (20 to $100 \mathrm{~km}$ apart), "areas within subregions" (10 to $15 \mathrm{~km}$ ), "fields within areas" (1 to $5 \mathrm{~km}$ ), and "locations within fields" (150 to $300 \mathrm{~m}$ ) (Fig. 1). The entire study area is considered a region in the context of Arizona agriculture. Four subregions contained two areas each and a fifth contained only one area. Each area consisted of three or four fields within a 3-km radius (Fig. 1). Within each field, locations at opposite corners were selected in order to maximize the estimate of within-field variance. Each location within a field contained three sites, $10 \mathrm{~m}$ apart. At each site, between 50 and $100 \mathrm{~g}$ of dry soil was collected from the soil surface (top 1 to $2 \mathrm{~cm}$ ) of a 3 by 3 $\mathrm{m}$ square. Samples were stored dry in cotton bags (Hubco soil sample bags, Forestry Products Supply, Jackson, MS) at room temperature $\left(23\right.$ to $27^{\circ} \mathrm{C}$ ) in order to allow similar treatment of all samples and to maximize stability of propagules in the soil during the assay period. 
Crop sequences in Yuma County are variable (Table 1). Sixteen cotton fields (fields 1 to 16) were selected in the fall of 1993 based on grower plans to plant lettuce (5 fields), crucifers (5 fields), or remain fallow (6 fields) during the winter of 1994. Of those, only 7 were replanted in cotton the following season. Thus, the three crop sequences became seven sequences by the following cotton season. In the winter of 1995, 14 additional fields were added to the study in a nested design (Fig. 1). Crop sequence data were recorded, but comparisons based on farmer plans were not incorporated into the design. Market conditions favored different crops from one year to the next and influenced which rotations could be observed. Sudan grass was fa- vored in the summer of 1994, cotton in the summer of 1995, and wheat in the winter of 1996. This provided an opportunity for comparisons of short crop sequences among subsets of the 30 fields selected for the nested spatial study.

Laboratory assays were performed within 100 days of sample collection. Repeat sampling from a subset of the bags indicated the A. flavus strain composition of the soil in the bags did not change within this time frame. The soil in each bag was mixed and a sub-sample (5 to 20 g) was suspended in $50 \mathrm{ml}$ of sterile water. Smaller sub-samples ( $5 \mathrm{~g}$ ) were used when previous experience suggested propagule densities would be high. The soil suspension $(0.2 \mathrm{ml})$ was spread on each of six 10-

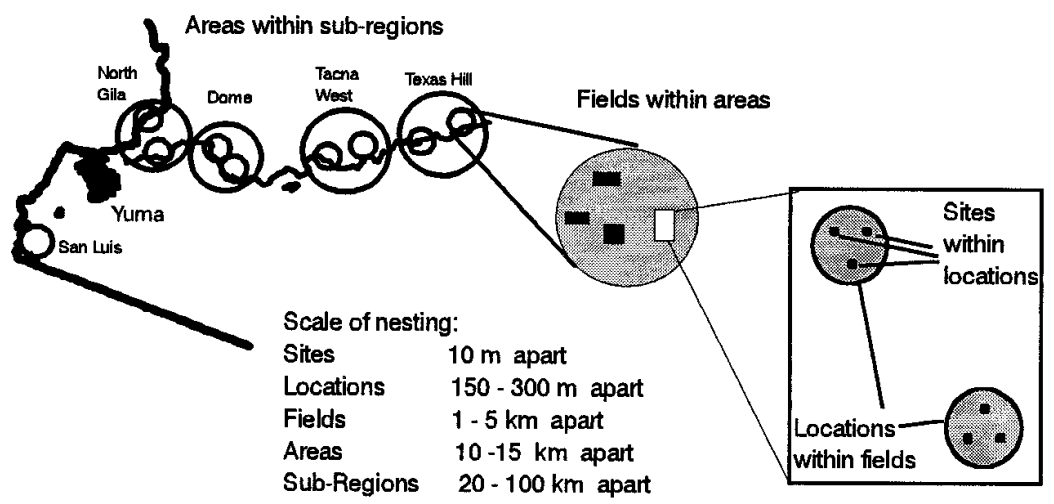

Fig. 1. Illustration of the nested sampling design used for the collection of soil samples from agricultural fields in Yuma County, Arizona.

$\mathrm{cm}$ petri plates containing a modified rose bengal agar medium (7). Plates were incubated for 3 days at $30^{\circ} \mathrm{C}$, after which $A$. flavus colonies were enumerated and transferred to $5 / 2$ agar plates (5\% V8 juice, $2 \%$ agar) for strain classification. Isolates were transferred by working outward from the center of selected dilution plates until 30 isolates were transferred per site. Isolates were classified as S or L strain on the basis of sclerotial formation on the $5 / 2$ medium within 4 days. $S$ strain isolates produced numerous small sclerotia.

The SAS statistical package (SAS Institute, Cary, NC) was used for analysis of variance (procedures GLM and NESTED) and for correlations (procedure CORR). PC ArcInfo and ArcView (version 1.0, ESRI, Redlands, CA) were used for geographical information system (GIS) analysis and display of the commercial field data. Propagule density (propagules per $g$ of soil) at each location was determined by averaging propagule counts from three bags of soil collected from sites $10 \mathrm{~m}$ apart. To determine strain composition, all isolates characterized from the three sites at each location were pooled and the percentage of S strain isolates determined. For analyses where it was critical to measure within field variance, and for correlations between locations within fields, only those fields where at least 45 isolates were characterized from all sites at each of the two locations were used (10 fields in March 1995, 16 fields in July 1995, and 26 fields

Table 1. Crop sequences for sampled fields

\begin{tabular}{|c|c|c|c|c|c|c|c|}
\hline \multirow[b]{2}{*}{ Subregion } & \multirow[b]{2}{*}{$\operatorname{Area}^{z}$} & \multirow[b]{2}{*}{ Field } & \multicolumn{5}{|c|}{ Crop } \\
\hline & & & Winter 1994 & Summer 1994 & Winter 1995 & Summer 1995 & Winter 1996 \\
\hline \multirow[t]{4}{*}{ San Luis } & 1 & 2 & Lettuce & Sudan & & Cotton & Lettuce \\
\hline & & 3 & Lettuce & Fallow & Lettuce & Cotton & Lettuce \\
\hline & & 10 & Crucifer & Fallow & & Cotton & \\
\hline & & 17 & & & Lettuce & Cotton & Wheat \\
\hline \multirow[t]{6}{*}{ North Gila } & 2 & 4 & Lettuce & Sudan & & Cotton & Corn \\
\hline & & 29 & Alfalfa & Alfalfa & Fallow & Cotton & Wheat \\
\hline & & 30 & Melon & Fallow & Lettuce/wheat & Fallow & Wheat \\
\hline & 3 & 5 & Lettuce & Cotton & Lettuce & Cotton & Wheat \\
\hline & & 27 & Lettuce & Cotton & Fallow & Cotton & Wheat \\
\hline & & 28 & Crucifer & Cotton & Fallow & Cotton & Wheat \\
\hline \multirow[t]{6}{*}{ Dome } & 4 & 9 & Crucifer & Sudan & & Cotton & Lettuce \\
\hline & & 25 & Wheat & & Crucifer & Corn & Corn \\
\hline & & 26 & Fallow & Cotton & Fallow & Cotton & Lettuce \\
\hline & 5 & 7 & Crucifer & Sudan & Fallow & Cotton & Lettuce \\
\hline & & 8 & Crucifer & Sudan & Fallow & Cotton & Lettuce \\
\hline & & 24 & & & Crucifer & Fallow & Lettuce \\
\hline \multirow[t]{6}{*}{ Tacna-West } & 6 & 16 & Fallow & Cotton & Fallow & Cotton & Fallow \\
\hline & & 22 & Lettuce & Cotton & Fallow & Cotton & Lettuce \\
\hline & & 23 & Fallow & Cotton & Fallow & Cotton & \\
\hline & 7 & 15 & Fallow & Cotton & Fallow & Cotton & Fallow \\
\hline & & 20 & Alfalfa & Alfalfa & Alfalfa & Alfalfa & Wheat \\
\hline & & 21 & Wheat & Sudan & Fallow & Cotton & Wheat \\
\hline \multirow[t]{8}{*}{ Texas Hill } & 8 & 13 & Fallow & Cotton & Wheat & Sudan & Fallow \\
\hline & & 14 & Fallow & Cotton & Wheat & Fallow & \\
\hline & & 18 & Alfalfa & Alfalfa & Alfalfa & Cotton & \\
\hline & & 19 & & & Fallow & Cotton & Wheat \\
\hline & 9 & 1 & Lettuce/wheat & Fallow & Lettuce & Cotton & Wheat \\
\hline & & 6 & Crucifer & Cotton & Fallow & Cotton & Lettuce \\
\hline & & 11 & Wheat & Fallow & Crucifer & Cotton & Crucifer \\
\hline & & 12 & Fallow & Cotton & Fallow & Cotton & Lettuce \\
\hline
\end{tabular}

\footnotetext{
${ }^{\mathrm{z}}$ Areas were located throughout the agricultural part of Yuma County, from Texas Hill to San Luis.
} 
in October 1995). Using locations with fewer than 45 isolates characterized introduced too much variability into the estimate of strain composition. For broader scale analyses where within-field variability was not an issue (Table 2), data from all sites at both locations within a field were pooled, and incidence of S strain was calculated without regard to within-field location. The number of isolates classified for each field is shown in Table 2.

\section{RESULTS}

A. flavus $\mathrm{S}$ strain was found in every field at each sampling period. The percentage of A. flavus isolates characterized as $\mathrm{S}$ strain (percent $S$ ) varied from $4 \%$ to $93 \%$ (Table 2). Using the variance between locations within fields for the error term, an analysis of variance of all areas indicated significant differences in percent $S$ strain among fields within areas in March $1995(P=0.0195)$, July $1995(P=0.0028)$, October $1995(P=0.0009)$, and March $1996(P=0.0013)$. Within two areas, there were pairs of fields that consistently differed in percent $S$ strain over the past four to five sampling periods: fields 5 and 28 in area 3, and fields 1 and 11 in area 9 (Table 2). Consistency among fields within areas over time was tested statistically by comparing means across all sampling dates using the interaction of sampling date and field as the error term in an analysis of variance; significant $(P=0.05)$ differences occurred in areas 3 and 9 (Table 2). The spatial relationships among fields in area 9 are illustrated in Figure 2. On each sampling date, field 1 had the greatest $S$ strain incidence (Fig. 2).

The basic spatial structure of A. flavus strain composition (as measured by percent S) was similar for all four sampling periods in 1995 and 1996 (Table 3). Most variance was observed among fields within areas $(47.4$ to $59.9 \%)$, which was successively greater than variance within fields (26.3 to $32.0 \%$ ), among subregions (12.0 to $20.8 \%$, and among areas within subregions $(0.0$ to $5.6 \%)$. The spatial scale among fields within areas is 1 to $5 \mathrm{~km}$. This was also the spatial scale of greatest variance in propagule density (Table 4). Variance among fields within areas (38.9 to $78.3 \%$ ) was greater than within fields (21.7 to $43.6 \%$ ). Variance among areas within subregions $(0.0$ to $16.6 \%)$ and among subregions $(0.0$ to $5.6 \%)$ was similar and less than the finer spatial scales.

By requiring characterization of at least 45 isolates per location prior to inclusion in the analysis of spatial structure, random error was kept low. This is demonstrated by the significant correlations among percent $\mathrm{S}$ values from different locations within fields (March 95, 10 fields, $r=$
$0.70, P=0.024$; July 95,16 fields $r=0.67$, $P=0.005$; October 95, 26 fields $r=0.68$, $P=0.0001$; March 96, 23 fields, $r=0.67$, $P=0.0004)$. The correlation coefficient for the relationship for all sampling dates was 0.69 . There was no correlation between strain composition and propagule density among fields for any of the five sampling dates ( $r=-0.26$ to $0.30 ; P=0.11$ to 0.69 ).

Crop sequences varied greatly among the fields (Table 1), but in 1995, 24 of the 30 fields were planted in cotton. A nested analysis of variance of $\mathrm{S}$ strain incidence, based only on the cotton fields, partitions the variance in almost exactly the same way as when all fields were included (plus or minus $1 \%$ of the values shown in Table 3 for July 95). Three pairs of crop sequences occurred at adequate frequency for statistical evaluation of crop sequence influence on A. flavus communities (Table 5). In most cases, no significant differences among crop sequences were detected. However, in 1995, propagule density was greater and the increase in $\mathrm{S}$ strain incidence lower in the "lettuce to cotton" than in the "fallow to cotton" sequence. Note that the "lettuce to cotton" sequence in 1995 included both extremes in S strain incidence: field 1 (March 91\%, July 93\%) and field 5 (March 6\%, July 12\%; Tables 1 and 2). Cotton was not planted in either 1994 or 1995 in three fields (fields 20, 25,

Table 2. Strain composition of Aspergillus flavus soil communities in 30 commercial fields in Yuma County

\begin{tabular}{|c|c|c|c|c|c|c|c|c|}
\hline \multirow[b]{2}{*}{ Subregion } & \multirow[b]{2}{*}{ Areaw $^{w}$} & \multirow[b]{2}{*}{ Field } & \multicolumn{6}{|c|}{ A. flavus isolates characterized as strain $\mathrm{S}(\%)$} \\
\hline & & & August 1994 & March 1995 & July 1995 & October 1995 & March 1996 & $\operatorname{Mean}^{x}$ \\
\hline \multirow[t]{4}{*}{ San Luis } & 1 & 2 & $40(43)^{\mathrm{y}}$ & $32(75)$ & $61(61)$ & $25(184)$ & $24(144)$ & $36 \mathrm{a}$ \\
\hline & & 3 & $36(77)$ & $46(84)$ & 65 (139) & 59 (167) & $63(140)$ & $54 \mathrm{a}$ \\
\hline & & 10 & $52(50)$ & $34(71)$ & 77 (126) & 87 (194) & 19 (154) & $54 \mathrm{a}$ \\
\hline & & 17 & $\mathrm{nd}^{\mathrm{z}}$ & $39(64)$ & $46(100)$ & 59 (126) & $53(80)$ & $49 \mathrm{a}$ \\
\hline \multirow[t]{6}{*}{ North Gila } & 2 & 4 & $63(54)$ & 40 (113) & 68 (176) & 38 (132) & $50(106)$ & $52 \mathrm{a}$ \\
\hline & & 29 & nd & 45 (104) & 66 (130) & $61(211)$ & $50(26)$ & $56 a$ \\
\hline & & 30 & nd & $53(32)$ & 34 (177) & $58(43)$ & 37 (27) & $46 \mathrm{a}$ \\
\hline & 3 & 5 & $44(48)$ & $6(138)$ & $12(232)$ & $11(180)$ & $6(151)$ & $16 \mathrm{~b}$ \\
\hline & & 27 & nd & $4(89)$ & $59(39)$ & 34 (132) & $14(108)$ & $28 \mathrm{~b}$ \\
\hline & & 28 & nd & $36(128)$ & $70(175)$ & $61(147)$ & 31 (108) & $50 \mathrm{a}$ \\
\hline \multirow[t]{6}{*}{ Dome } & 4 & 9 & 87 (39) & $49(67)$ & 60 (116) & 72 (158) & $26(99)$ & $59 a$ \\
\hline & & 25 & nd & $30(205)$ & $54(224)$ & 45 (213) & 28 (139) & $39 a$ \\
\hline & & 26 & nd & $21(252)$ & $61(254)$ & 33 (175) & $32(125)$ & $37 \mathrm{a}$ \\
\hline & 5 & 7 & $79(53)$ & $24(66)$ & $75(151)$ & 35 (154) & 19 (118) & $46 \mathrm{a}$ \\
\hline & & 8 & $71(55)$ & $43(60)$ & 47 (144) & $11(173)$ & $8(145)$ & $36 \mathrm{a}$ \\
\hline & & 24 & nd & $29(56)$ & $77(90)$ & $40(98)$ & $50(105)$ & $49 \mathrm{a}$ \\
\hline \multirow[t]{6}{*}{ Tacna-West } & 6 & 16 & $59(64)$ & $25(52)$ & $77(81)$ & $35(200)$ & 46 (139) & $44 \mathrm{a}$ \\
\hline & & 22 & nd & $36(99)$ & 55 (152) & 15 (172) & 9 (114) & $29 \mathrm{a}$ \\
\hline & & 23 & nd & 49 (117) & 32 (173) & 32 (173) & 35 (148) & $37 \mathrm{a}$ \\
\hline & 7 & 15 & $32(56)$ & $25(218)$ & 35 (256) & 13 (154) & $26(141)$ & $24 \mathrm{a}$ \\
\hline & & 20 & nd & 74 (153) & 38 (123) & 39 (171) & $21(110)$ & $43 \mathrm{a}$ \\
\hline & & 21 & nd & $46(39)$ & 76 (107) & 63 (198) & 29 (117) & $54 \mathrm{a}$ \\
\hline \multirow[t]{8}{*}{ Texas Hill } & 8 & 13 & $44(52)$ & $30(50)$ & $90(51)$ & $74(81)$ & $28(89)$ & $53 \mathrm{a}$ \\
\hline & & 14 & $82(50)$ & $39(97)$ & $34(67)$ & $36(73)$ & $24(88)$ & $43 \mathrm{a}$ \\
\hline & & 18 & nd & $31(81)$ & 85 (164) & 59 (171) & $36(152)$ & $53 \mathrm{a}$ \\
\hline & & 19 & nd & $37(40)$ & 79 (182) & $83(185)$ & 67 (186) & $67 \mathrm{a}$ \\
\hline & 9 & 1 & $83(81)$ & $91(151)$ & $93(150)$ & $76(165)$ & 86 (162) & $86 \mathrm{a}$ \\
\hline & & 6 & $66(65)$ & $35(80)$ & 87 (150) & $63(155)$ & $78(126)$ & $66 \mathrm{~b}$ \\
\hline & & 11 & $44(41)$ & $50(36)$ & $52(113)$ & $51(145)$ & 29 (133) & $45 \mathrm{c}$ \\
\hline & & 12 & $65(55)$ & $56(88)$ & 86 (118) & 68 (136) & $66(122)$ & $68 \mathrm{~b}$ \\
\hline
\end{tabular}

w Areas were located throughout the agricultural part of Yuma County from Texas Hill to San Luis.

${ }^{x}$ Means followed by the same letter are not significantly different from means of other fields within the same area by the Duncan's multiple range test $(P=$ 0.05) using the interaction of sampling date and field as the error term.

y Number of isolates characterized are in parentheses following the percent Strain S.

z No data. Data were collected from 16 fields in 1994 and 30 fields in 1995 and 1996. 
30). S strain incidence in these fields ranged from 21 to $74 \%$ and did not appear to differ from other fields in their respective areas (Table 2).

The subregions were an important source of variance for strain composition (Table 3), but not for propagule density (Table 4). The Texas Hill subregion had a significantly higher incidence $(P=0.05)$ of the $S$ strain (averaged over the five sampling times) than any of the other subregions (Fig. 3A). However, there was no evidence for a subregional pattern in $A$. flavus propagule density (Fig. 3B). Both S strain incidence and A. flavus propagule density were greater in August 1994 and July 1995 than in March 1995 and March 1996 (Fig. 4A and 4B).

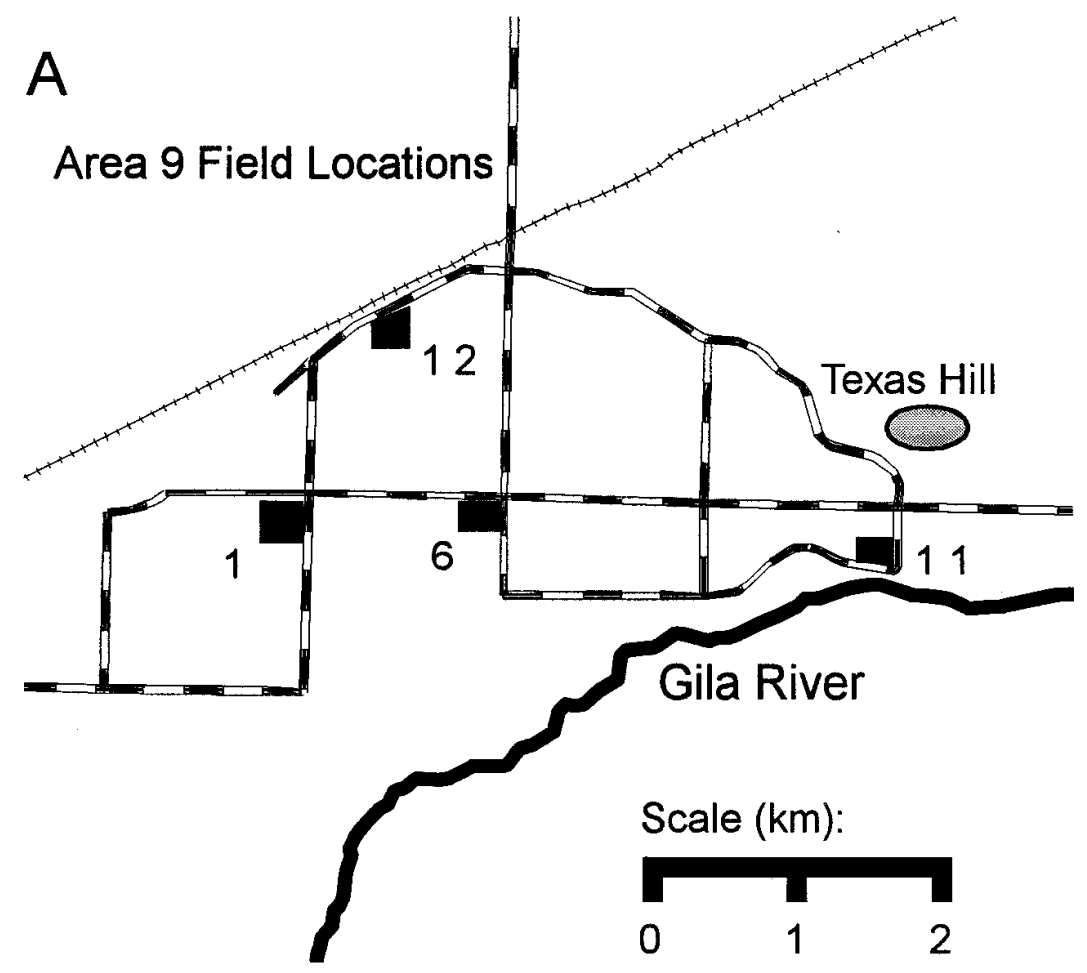

B

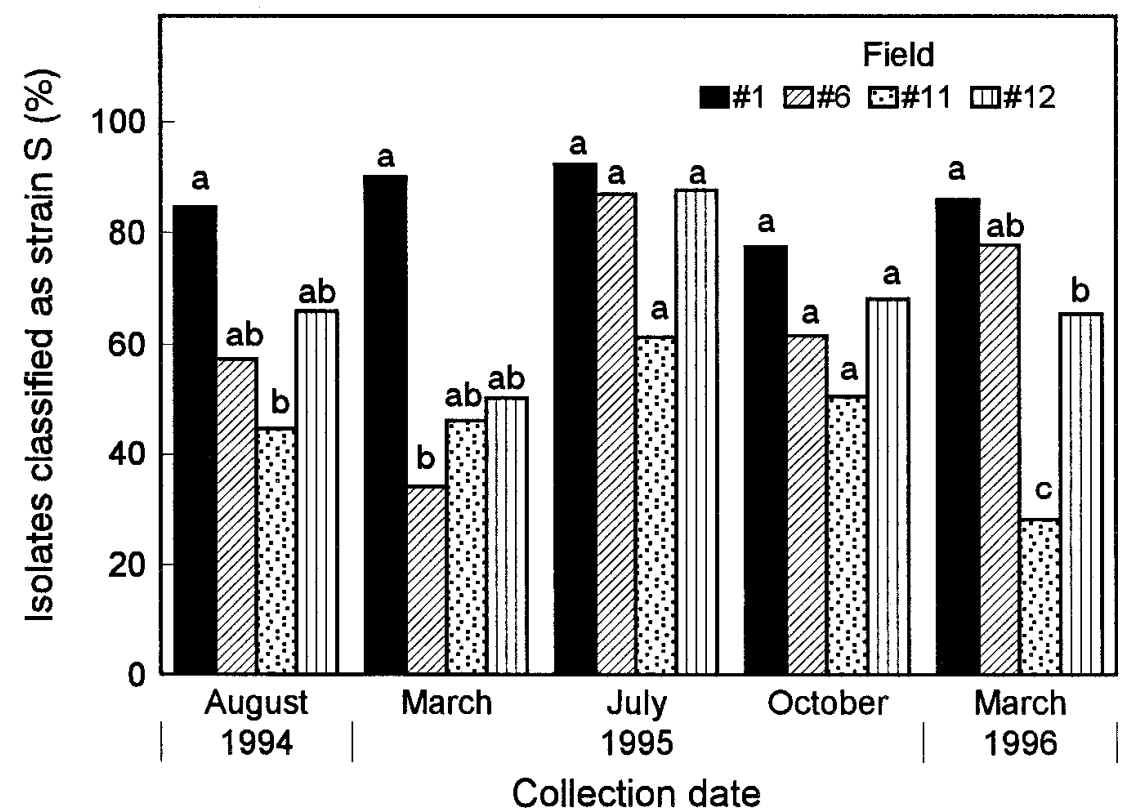

Fig. 2. Spatial and temporal pattern of Aspergillus flavus strain S incidence. (A) Fields in area 9 are located in a 3-km-wide strip of agriculture between the railroad tracks on the north and the Gila River on the south, with desert beyond. (B) Within each collection date, bars with the same letter are not significantly different by Duncan's multiple range test $(P=0.05)$.

\section{DISCUSSION}

Many studies of the spatial structure of soil population magnitude have examined within-field variability for various fungal genera and species (3), but few have characterized spatial structure across orders of magnitude of spatial scale, and none have compared the spatial scale of variability in propagule density with the spatial scale of variability in fungal strain composition. In the current study, partitioning of variance indicated that most variability in both $A$. flavus propagule density and strain composition of communities occurred among fields within areas. This corresponds to the spatial scale of 1 to $5 \mathrm{~km}$. Cropping sequences are complex in this region, and fields typically have multiple crops in a single year. Crop rotation, in this study, explained relatively little of the observed variability in strain composition. The extremes in S strain incidence, field 1 (averaging 86\% $\mathrm{S}$ strain) and field 5 (averaging $16 \% \mathrm{~S}$ strain), had identical sequences in 1995 and 1996 (lettuce to cotton to wheat).
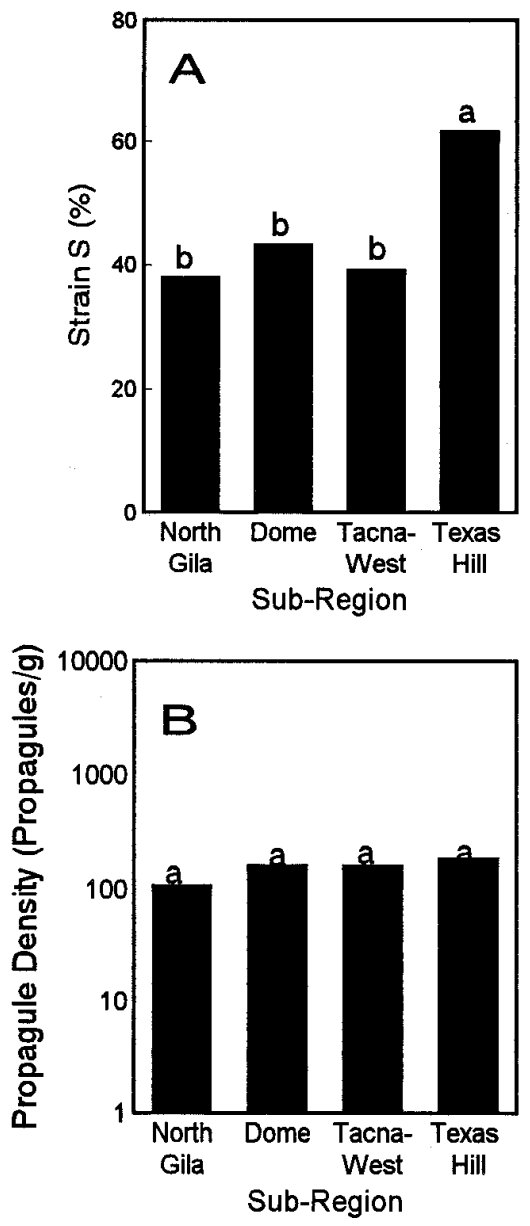

Fig. 3. (A) Aspergillus flavus strain composition and (B) propagule density among subregions in Yuma County, Arizona, averaged over five collection dates from August 1994 through March 1996. Bars with the same letter are not significantly different by Duncan's multiple range test $(P=0.05)$. 
Although sampling in the current study extended over less than 2 years, the composition of several fields (for example, fields 10 and 13) varied widely over time. This indicates A. flavus community composition may shift rapidly. The observed increased propagule density of A. flavus in the hot dry summer months in Arizona is consistent with previous reports (11), but a seasonal shift in strain composition at the regional scale has not been reported previously. Despite the similarity in temporal patterns of the strain composition and propagule density variables when averaged over the entire region, there was no correlation between propagule density and strain composition at the field level. This suggests that the preferential increase of the $S$ strain in soil may occur both in soils that are highly favorable to A. flavus increases, and in those that are only marginally favorable. The most obvious difference in the sampling times is temperature, but many variables, such as soil condition, day length, crop sequence history, insect levels, fungicide application history, irrigation water quality, and irrigation frequency may influence A. flavus communities. However, selective forces which favor differential strain success are not known. Rapid changes in the composition of A. flavus vegetative compatibility groups in a Yuma County cotton field have been attributed to founder effects caused by a few VCGs establishing early in the crop (1).

Fields within certain areas (for example, areas 3 and 9) retained significant differences in strain composition over time. Apparently, some factor other than crop rotation, with variability at the 1 to $5 \mathrm{~km}$ scale, is influencing strain composition. Potential factors include soil type, irrigation source and frequency, tillage practices, and micro-climatic factors. Identification of the putative factor may permit development of techniques to reduce $\mathrm{S}$ strain incidence and, in so doing, reduce aflatoxin producing potential of A. flavus communities. None of the fields within the present study were adjacent to each other. Future

Table 3. Description of the spatial scale of Aspergillus flavus strain composition using components of variance from a nested analysis of variance ${ }^{\mathrm{z}}$

\begin{tabular}{lcrrrr}
\hline & & \multicolumn{3}{c}{ Percent total variance } \\
\cline { 3 - 5 } & & \multicolumn{3}{c}{$\mathbf{1 9 9 5}$} & $\mathbf{1 9 9 6}$ \\
\cline { 3 - 5 } Variance source & Spatial scale (km) & March & July & October & March \\
\hline Among subregions & $>20$ & 12.0 & 19.9 & 20.8 & 13.8 \\
Among areas within subregions & $10-15$ & 0.0 & 0.0 & 0.0 & 5.6 \\
Among fields within areas & $1-5$ & 59.9 & 53.8 & 47.4 & 48.6 \\
Among locations within fields & $0.2-0.4$ & 28.1 & 26.3 & 31.8 & 32.0 \\
Total & & 100.0 & 100.0 & 100.0 & 100.0 \\
\hline
\end{tabular}

${ }^{\mathrm{z}}$ The nested sampling design is illustrated in Figure 1. Strain composition (the percentage of isolates that are strain $\mathrm{S}$ ) was determined by characterizing at least 45 isolates representing three sites located $10 \mathrm{~m}$ apart at each location.

Table 4. Description of the spatial scale of Aspergillus flavus propagule density using the components of variance from a nested analysis of variance ${ }^{z}$

\begin{tabular}{lcrrrr}
\hline & \multicolumn{3}{c}{ Percent total variance } \\
\cline { 3 - 5 } & & \multicolumn{3}{c}{$\mathbf{1 9 9 5}$} & $\mathbf{1 9 9 6}$ \\
\cline { 3 - 5 } Variance source & Spatial scale (km) & March & July & October & March \\
\hline Among subregions & 20 & 0.0 & 0.0 & 0.9 & 5.6 \\
Among areas within subregions & $10-15$ & 0.0 & 14.0 & 16.6 & 0.0 \\
Among fields within areas & $1-5$ & 78.3 & 62.2 & 38.9 & 70.8 \\
Among locations within fields & $0.2-0.4$ & 21.7 & 23.8 & 43.6 & 23.6 \\
Total & & 100.0 & 100.0 & 100.0 & 100.0 \\
\hline
\end{tabular}

${ }^{z}$ The nested sampling design is illustrated in Figure 1. Propagule density (propagules per $g$ of soil) at each location was determined by averaging propagule counts from three bags of soil collected from sites $10 \mathrm{~m}$ apart. efforts to understand the influence of landscape variables on the A. flavus community in Yuma County soils should concentrate on a scale of about $5 \mathrm{~km}$ and include the sampling of adjacent fields in order to partition short range spatial structure within and between fields.

Patterns in A. flavus strain composition were contrasted with patterns in A. flavus propagule density in order to better understand factors influencing the aflatoxin contamination of cottonseed. The expectation that the strain composition of the $A$. flavus community can affect the aflatoxin level in the cotton crop is based on field plot studies (8). In plots where the soil surface was treated with wheat kernels inoculated with atoxigenic strains of $A$. flavus, infected cotton bolls had significantly lower aflatoxin levels than infected cotton bolls in untreated control plots (8). These field plot studies are supported by greenhouse studies that show that atoxigenic strains have the capacity to competitively exclude toxigenic strains from wound sites on cotton bolls $(5,10)$. It is much more difficult to develop evidence of the effect of strain toxigenicity on aflatoxin levels in commercial fields for at least two reasons. First, many factors other than strain toxigenicity influence aflatoxin levels (for example, high variation in pink bollworm infestation might mask effects of strain composition). Second, special coordination with farmers and gins is required to associate aflatoxin levels at the gins with particular fields. Studies such as the one reported here help build a foundation for commercial field studies which, in the future, may be able to relate strain composition to aflatoxin levels in the crop.

Results of the current study highlight variation among fields within areas, but subregional patterns were also observed. Fields in the Texas Hill subregion were, on average, consistently greater in $\mathrm{S}$ strain incidence than fields in other subregions. Thus, the Texas Hill subregion may have some broad characteristic that gives a competitive advantage to the S strain. Although significantly lower than Texas Hill, the percent $\mathrm{S}$ averages for the other three subregions in Yuma County (40 to 50\%) are high compared with those observed in other cotton producing areas where regional averages are frequently below $20 \%$ S strain (6). S strain incidence along Mari-

Table 5. Comparison of changes in Aspergillus flavus propagule density and strain $\mathrm{S}$ incidence for selected crop sequences

\begin{tabular}{|c|c|c|c|c|c|c|c|c|c|c|}
\hline \multicolumn{2}{|c|}{ Temporal sequence } & \multicolumn{2}{|c|}{ Crop sequence } & \multirow[b]{2}{*}{ No. of fields (n) } & \multicolumn{3}{|c|}{ Propagule density (prop/g) } & \multicolumn{3}{|c|}{ Strain S incidence (\%) } \\
\hline Time 1 & Time 2 & Time 1 & Time 2 & & Time 1 & Time 2 & Change & Time 1 & Time 2 & Change \\
\hline \multirow{2}{*}{$\overline{\text { Summer } 94}$} & Summer 95 & Sudan & Cotton & 5 & $1,008^{\mathrm{y}}$ & 502 & -506 & 68 & 62 & -6 \\
\hline & & Cotton & Cotton & 5 & 1,685 & 1591 & -94 & 53 & 59 & 6 \\
\hline \multirow[t]{2}{*}{ Winter 95} & Summer 95 & Lettuce & Cotton & 4 & 193 & $5662 * \mathrm{z}$ & $5,469 *$ & 46 & 54 & $8^{*}$ \\
\hline & & Fallow & Cotton & 13 & 178 & $814^{*}$ & $636^{*}$ & 34 & 64 & $30 *$ \\
\hline \multirow[t]{2}{*}{ Summer 95} & Winter 96 & Cotton & Lettuce & 9 & 1,275 & 53 & 1,222 & 66 & 36 & -30 \\
\hline & & Cotton & Wheat & 8 & 2,868 & 85 & 2,783 & 63 & 42 & -21 \\
\hline
\end{tabular}

${ }^{\mathrm{y}}$ The values for propagule density and strain $\mathrm{S}$ incidence are means.

$\mathrm{z} *$ indicates crop sequences are different statistically by Wilcoxon's rank-sum test $(P<0.05)$. 

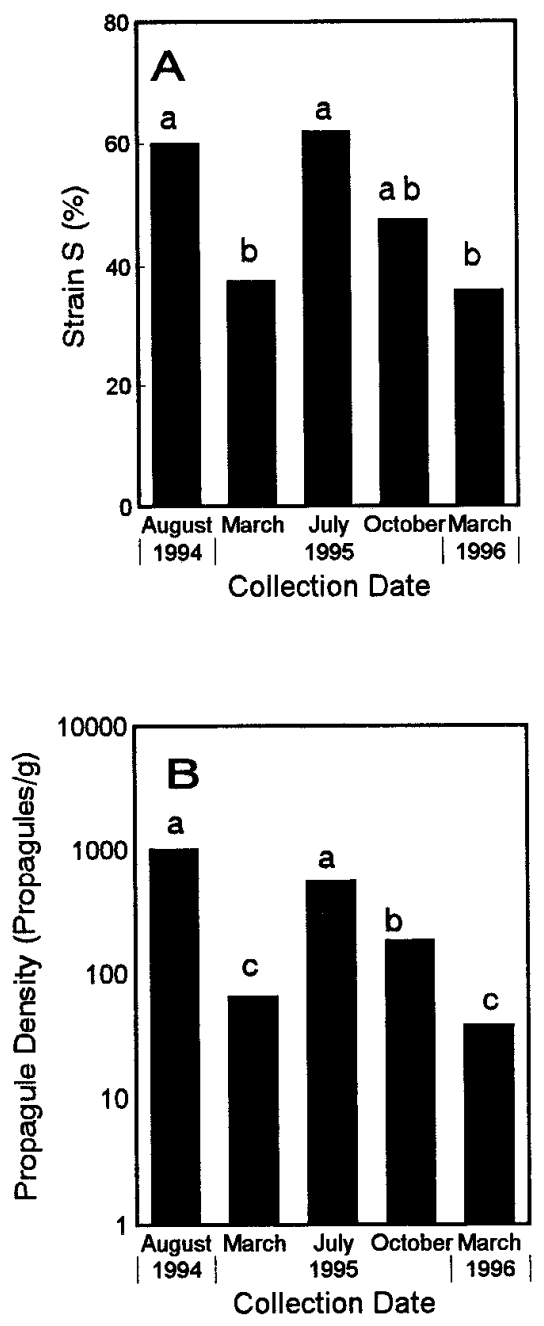

Fig. 4. (A) Aspergillus flavus strain composition and (B) propagule density averaged over all fields in all subregions at five collection dates from August 1994 through March 1996. Bars with the same letter are not significantly different by Duncan's multiple range test $(P=0.05)$.

copa Road in Pinal County, Arizona, was less than 10\% in 1989 and 1993 (9).

References to spatial and temporal patterns in aflatoxin studies have been more general than the present study. Manabe and Tsuruta (13) found that the proportion of aflatoxin-producing fungi increased as one approached the tropics in Southeast Asia, but they compared species rather than strains, and at the continental scale rather than the regional scale. Marsh and Taylor's geographic study (14) of A. flavus-caused fluorescent spots on cotton fiber was also framed at the continental scale. Russell et al (16) described, in broad terms, temporal and spatial patterns in aflatoxin levels on harvested cotton, and remarked on a high level of "field to field within an area" variation. Understanding patterns of $A$. flavus strain composition and propagule density may lead to a better understanding of variability in aflatoxin contamination. Spatial and temporal dynamics of A. flavus communities at the subregional scale will influence the success of efforts to modify toxigenicity of $A$. flavus communities through application of atoxigenic L strain isolates. Whether interpreting the results of large scale atoxigenic strain field trials or assessing the impact of cultural management practices, current results suggest variability at the 1 to $5 \mathrm{~km}$ scale will be important in the Yuma County soils.

\section{ACKNOWLEDGMENTS}

This work was supported by a grant from the Multicrop Working Group of the Aflatoxin Elimination Program through USDA cooperative agreement \# 58-6435-4-115.

\section{LITERATURE CITED}

1. Bayman, P., and Cotty, P. J. 1991. Vegetative compatibility and genetic diversity in the Aspergillus flavus population of a single field. Can. J. Bot. 69:1707-1711.

2. Bayman, P., and Cotty, P. J. 1993. Genetic diversity in Aspergillus flavus: association with aflatoxin production and morphology. Can. J. Bot. 71:23-31.

3. Campbell, C. L., and Madden, L. V. 1990. Introduction to Plant Disease Epidemiology. John Wiley and Sons, New York.

4. Cotty, P. J. 1989. Virulence and cultural characteristics of two Aspergillus flavus strains pathogenic on cotton. Phytopathology 79:808-814.

5. Cotty, P. J. 1990. Effect of atoxigenic strains of Aspergillus flavus on aflatoxin contamination of developing cottonseed. Plant Dis. 74:233-235.

6. Cotty, P. J. 1992. Soil populations of Aspergillus flavus group fungi in agricultural soils in Alabama, Arizona, Louisiana, and Mississippi. (Abstr.) Phytopathology 82:1064.

7. Cotty, P. J. 1994. Comparison of four media for the isolation of Aspergillus flavus group fungi. Mycopathologia 125:157-162.

8. Cotty, P. J. 1994. Influence of field application of an atoxigenic strain of Aspergillus flavus on the populations of A. flavus infecting cotton bolls and on the aflatoxin content of cottonseed. Phytopathology 84:1270-1277.

9. Cotty, P. J. 1997. Aflatoxin-producing potential of communities of Aspergillus section Flavi from cotton producing areas in the United States. Mycol. Res. 101:698-704.

10. Cotty, P. J., and Bayman, P. 1993. Competitive exclusion of a toxigenic strain of Aspergillus flavus by an atoxigenic strain. Phytopathology 83:1283-1287.

11. Cotty, P. J., Bayman, P., Egel, D. S., and Elias, K. S. 1994. Agriculture, Aflatoxins, and Aspergillus. Pages 1-27 in: The Genus Aspergillus. K. A. Powell, A. Renwick, and J. F Peberdy, eds. Plenum Press, New York.

12. Goldblatt, L. A., and Stoloff, L. 1983. History and natural occurrence of aflatoxins. Pages 33-46 in: Proc. Int. Symp. on Mycotoxins. Food and Drug Administration, Rockville Maryland and National Research Centre, Cairo, Egypt.

13. Manabe, M., and Tsuruta, O. 1978. Geographical distribution of aflatoxin-producing fungi inhabiting in Southeast Asia. Jpn. Agric. Res. Q. 12:224-227.

14. Marsh, P. B., and Taylor, E. E. 1958. The geographical distribution of fiber containing fluorescent spots associated with Aspergillus flavus in the United States cotton crop of 1957. Plant Dis. Rep. 42:1368-1371.

15. Oliver, M. A., and Webster, R. 1986. Combining nested and linear sampling for determining the scale and form of spatial variation of regionalized variables. Geograph. Anal. 18:227-242.

16. Russell, T. E., Lee, L. S., and Buco, S. 1987. Season formation of aflatoxins in cottonseed produced in Arizona and California. Plant Dis. 71:174-177.

17. Webster, R., and Boag, B. 1992. Geostatistical analysis of cyst nematodes in soil. J. Soil Sci. 43:583-595.

18. Wolf, H., and Jackson, E. W. 1963. Hepatomas in rainbow trout: Descriptive and experimental epidemiology. Science 142:676678. 